\title{
SERVICE RECOVERY STRATEGIES AND PERCEIVED JUSTICE: THE MODERATING ROLE OF PSYCHOLOGICAL CONTRACT VIOLATION
}

\author{
Rania Mostafa, University of Leeds, UK \\ Cristiana Raquel Lages, Loughborough University, UK
}

\begin{abstract}
Based on equity theory and prospect theory, this paper explores for the first time the moderating effect of Psychological Contract Violation (PCV) in the relationship between service recovery strategies and perceived justice. Findings from 29 indepth interviews revealed the moderating role of PCV, which was later tested using a survey instrument. Ping's (1995) and Cadogan et al.'s (2006) procedures for assessing the structural model with interaction terms were followed.

Results based on a sample of 437 complaining customers demonstrated that customers who perceive the failure as PCV tend to expect more from the firm as an attempt to recover from the damage they experienced due to the failure. In particular, when the customer perceives the failure as a PCV, the added value of each service recovery strategy is smaller and the impact on customers' perception of justice is weaker. Theoretical and managerial implications of incorporating the PCV in the service recovery context are discussed.

References available upon request
\end{abstract}

